\title{
Notes on the New Edition \\ of Marcello's II teatro alla moda
}

\author{
Klára Škrobánková
}

Benedetto Marcello. Divadlo podle módy. Ed. Jana Spáčilová and Ondřej Šmíd. Praha: Psalterium, 2020.

Three centuries after the initial publication of Benedetto Marcello's famous satirical pamphlet on the Italian opera $\mathrm{Il}$ teatro alla moda (Venice, 1720) and half a century after the first publication in Czech, opera lovers have the opportunity to read Alena Hartmanová's translation in a new edition prepared by the musicologists Jana Spáčilová and Ondřej Šmíd. The pocketsized book is an important source of information about the Italian opera customs in the early $1700 \mathrm{~s}$, the rivalling operatic schools and the relationships between the various artistic trades and professions. In twenty-seven short chapters, Marcello addresses various groups of artists and their associates, starting with poets and singers and concluding with mothers of young actresses and owners of theatre restaurants. Each member of these groups is given highly sarcastic advice on how to behave in theatre, write an opera, or sing properly. Marcello's advice reveals the author's dissatisfaction with the state of opera in Venice as well as the everyday reality of theatre creators and performers. Despite focusing on opera, Il teatro alla moda is an unrivalled source of understanding Baroque festivities and the lifestyle of the wealthy citizens of Italy and Central Europe.

Reissuing already existing books from the artistic field is not common, and the Czech reader is often left searching for secondhand copies or borrowing well worn study material from the library. The 2020 re-edition of the Italian pamphlet is, therefore, a rare event worthy of academic attention. Hartmanová's 1970 translation of Il teatro alla moda (Divadlo podle módy), supplemented by an opening study written by Czech musicologist Josef Bachtík, has been sold out since the 1970 s, thus making the new edition more than necessary. Additionally, as Spáčilová mentions in the Foreword, scholarly understanding of baroque opera has changed significantly in the last decades. New findings have emerged from the consistent research of archival materials on the early opera. The work of specialized ensembles performing exclusively Baroque music and occasionally staging operas in the preserved or reconstructed Baroque theatres offered an insight into period practice with its challenges and shortcomings. The new edition of the Italian pamphlet takes all these findings into account and carefully explains the circumstances which led Marcello to publish his merciless commentary on the state of the Italian art of the early $18^{\text {th }}$ century. The first Czech version did include some explanatory footnotes, yet the editors of the reissue reworked and almost tripled the number of notes. The majority of notes can be found in the first two chapters, "To the Poets" and "To the 
Composers", dealing with the questions of score, libretti, or acting techniques. These footnotes cannot be seen as simple explanations of obscure terms and situations; they provide valuable information on the driving forces behind the creation of the operatic pieces. These are not given as plain facts, but rather offer multiple viewpoints contextualizing individual cases within a wider baroque culture. The editors often provide relevant circumstantial information and compare period practice with present day operatic tradition, reminding the reader of elements of the text that might have otherwise been lost in the cultural translation. This, for instance, is the case of the footnote (no. 57) that points out that tenors and basses are mentioned only towards the end of the chapter about singers, suggesting that for Marcello and his peers, singers were predominantly castrati. When talking about singers, the author was thus not talking about all the male singing voices but only about the castrati.

Besides the revised annotations, the new edition of Il teatro alla moda features the facsimiles of the Italian original print from 1725, printed on facing pages with the Czech translation, respecting the Italian pagination. The Italian text might seem to be useful only for Italian speakers, but it could, in fact, be beneficial to anyone. Marcello's pamphlet occasionally discusses the poor rhyming and linguistic skills of the librettists, demonstrating these on well-chosen examples. Despite Hartmanová's effort, the onomatopoeic quality of the Italian text is quite understandably lost in the translation. However, with the Italian original on the side, one can promptly find the discussed words and enjoy their sounds even without understand- ing their meaning. The bilingual edition is also useful for understanding the regional dialects and differences of the Italian language. A running joke of the pamphlet, the Bolognese accent and manners, is virtually impossible to translate. The editors talk about the untranslatability of the accent and Marcello's reasons for ridiculing Bologna in the footnotes, and the Italian original helps with understanding the specificity of the language variety and its comicality. Once again, it is not necessary to speak Italian to perceive the difference between the language of the pamphlet and the short excerpts in the Bolognese language variant as it is full of one-syllable words and contractions.

The pamphlet opens with a Foreword by Jana Spáčilová, a leading Czech expert on Baroque opera, in which she outlines Marcello's career and discusses the peculiarities of the treatise's original frontispiece, uncovering the hidden satire behind the engraving of a man and a bear on a boat. Spáćilová also mentions the unique connection between Il teatro alla moda and the Czech lands - in 1724, Count František Antonín Spork invited a Venetian troupe to perform Italian opera at his Prague palace, which led to an increase in popularity of opera in the heart of Europe. Furthermore, two singers listed on the title page of the pamphlet are known to have later also performed in Prague. The Afterword by the musicologist Ondřej Šmíd presents a rather poetic contemplation on the value of Baroque art in contemporary society. It could certainly do without generalizations about gender and technology, which downgrade the otherwise exceptional publication.

The overall quality and merit of the new Czech edition are evident. Therefore, it is 
saddening to see the publisher's inability and then leave it in the storehouse, deto distribute the book to the Czech pub- spite its undeniable academic value. Marlic and university libraries and begin with cello's treatise has a lot to offer to the nonthe sale of the book. The worldwide pan- specialist reader, even more so if provided demic certainly complicates all things, but with the careful footnotes that draw the it would be regrettable to publish a book elaborate picture of Italian baroque opera. 